\title{
Hepatitis B virus infection among staff in three hospitals in Khartoum, Sudan, 2006-07
}

A.H. Elduma ${ }^{7}$ and N.S. Saeed ${ }^{l}$

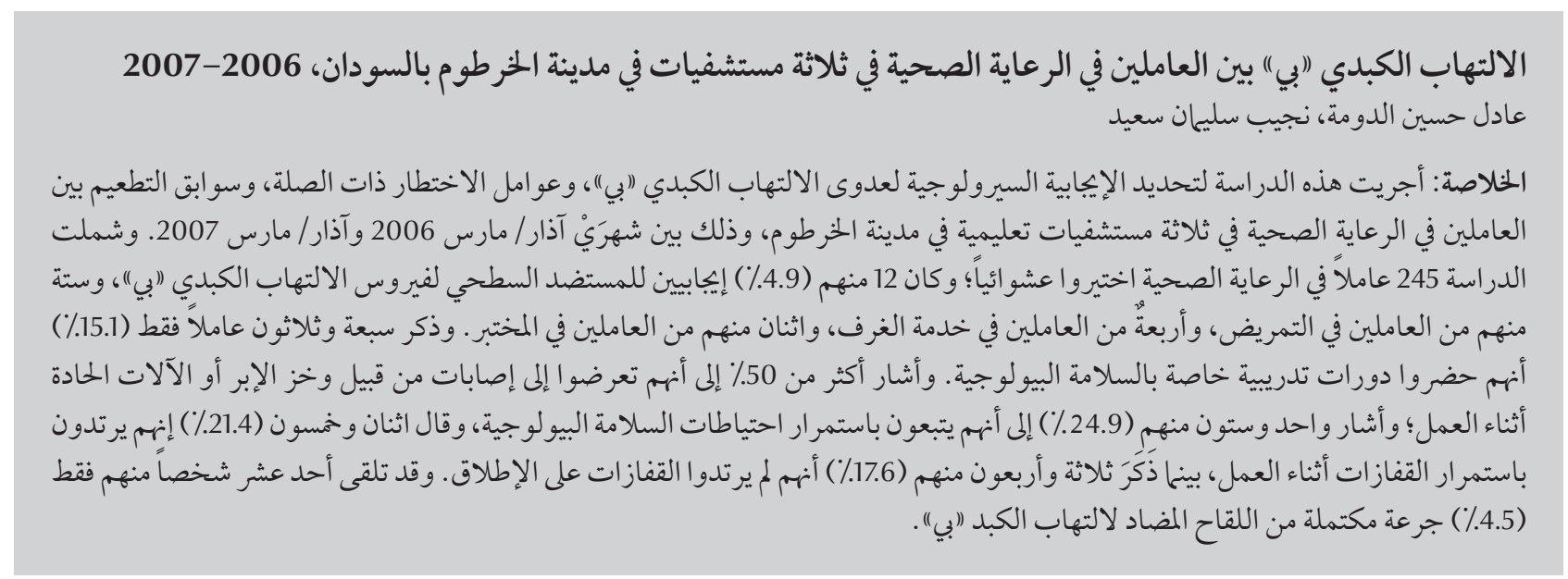

ABSTRACT This study was conducted to determine the seropositivity of hepatitis B infection, associated risk factors and history of vaccination among staff in 3 teaching hospitals in Khartoum. The study was carried out from March 2006 to March 2007. Participants comprised 245 randomly selected hospital staff; 12 (4.9\%) reacted positively for HBsAg, 6 of whom were nurses, 4 domestic staff and 2 laboratory staff. Only 37 participants (15.1\%) said that they had attended training courses in biosafety. Just over $50 \%$ indicated that they had had needle-stick or sharps injuries during work; 61 (24.9\%) indicated that they always followed the bio-safety precautions, 52 (21.4\%) said that they always wore gloves during their work while 43 (17.6\%) said they never wore them. Only 11 (4.5\%) of the participants had received the full vaccination dose for hepatitis B.

Infection par le virus de I'hépatite B chez les agents de santé de trois hôpitaux à Khartoum (Soudan) entre 2006 et 2007

RÉSUMÉ La présente étude a été conduite pour déterminer la séropositivité pour l'infection par le virus de I'hépatite B dans le personnel de trois hôpitaux universitaires de la ville de Khartoum, les facteurs de risques associés en la matière et leurs antécédents vaccinaux. L'étude a été réalisée de mars 2006 à mars 2007. Les participants comptaient 245 personnels hospitaliers sélectionnés de façon aléatoire ; sur douze cas positifs (4,9\%) pourl'AgHBs, six faisaient partie du personnel infirmier, deux du personnel de laboratoire et quatre étaient des agents d'entretien. Seuls 37 participants (15,1\%) ont déclaré avoir participé à des cours de formation sur la sécurité biologique. À peine plus de $50 \%$ des répondants ont indiqué avoir été blessés par piqûre d'aiguille ou objet tranchant pendant leur travail ; 61 (24,9\%) ont précisé qu'ils prenaient toujours les précautions de sécurité biologique, 52 (21,4 \%) déclaraient toujours porter des gants au travail, alors que 43 agents (17,6 \%) affirmaient ne jamais en porter. Seuls onze participants $(4,5 \%)$ avaient reçu les doses complètes de vaccin contre l'hépatite B. 


\section{Introduction}

Hepatitis B virus (HBV) is a causative agent of hepatitis infection, which is asymptomatic in most individuals, but it can show features of fulminant, acute, or chronic hepatitis. The acute type produces serious illness and approximately $0.5 \%$ of cases are fatal. Chronic infection is often lifelong, and can lead to liver failure and hepatocellular carcinoma [1].

Transmission of HBV is through the parenteral route, blood transfusion products and sexual intercourse and vertically from infected mothers to neonates. The virus is found in body fluids such as urine, saliva, nasopharyngeal fluids, semen and menstrual fluids, and can be transmitted through contact with these fluids [2].

Hepatitis B virus is the most commonly transmitted bloodborne virus in the health-care setting. Transmission generally occurs from patient to patient or from patients to health-care personnel via contaminated instruments or accidental needle-stick or sharps injuries. The virus can be transmitted directly through body fluids to mucous membranes, cutaneous scratches, abrasions, burns or other lesions. Indirect transmission can occur from surfaces contaminated with blood or body fluids to mucous membranes. HBV has been shown to survive in dried blood on surfaces at room temperature for at least a week [3]. The risk of HBV infection among health-care workers is 3-5 times higher than in the general population: in particular, surgeons, pathologists, physicians, laboratory staff, domestic staff and nurses have the highest risk of infection [4]. Research findings have indicated that $10 \%-30 \%$ of health-care workers show serologic evidence of past or present HBV infection [5].

Hepatitis B virus infection is common in Sudan in all age groups. In a seroprevalence study carried out in Juba, Southern Sudan, in 1993 on 666 patients attending Juba Hospital, 26\% were $\mathrm{HBsAg}$ positive [6]. In another study among soldiers in 5 urban localities, $78 \%$ had evidence of past infection [7]. In a study conducted in eastern Sudan on people in high-risk groups (prostitutes, long distance truck drivers and soldiers), positivity for HBsAg was 14\% [8]. The epidemiology of hepatitis B was also studied in central Sudan, Gezira area, where HBsAg positivity was $14 \%$ [9]. In a study conducted in Omdurman among adults with acute hepatitis, HBV infection was $12.6 \%$ [10]. Similarly, $12.4 \%$ of patients attending a surgical unit were positive for HBsAg [11]. Sudan is considered highly endemic for HBsAg, with prevalence about $16 \%-20 \%$ in the general population [12].

As there are no recent and accurate data available in Sudan regarding infection with $\mathrm{HBV}$ in healthcare workers. This study was conducted to determine the prevalence of infection among healthcare personnel from what are considered high risk groups working in Khartoum teaching hospitals. In addition, risk factors associated with infection were also studied and the status of hepatitis $B$ vaccination and health-care workers who need to be vaccinated were determined.

\section{Methods}

This study was conducted between March 2006 and March 2007. Three public hospitals were selected to participate in this cross-sectional survey to collect data from personnel, Omdurman, Khartoum and Khartoum North hospitals. Health-care staff (surgeons, nurses, domestic staff, laboratory staff, and dentists) working in these hospitals were selected to participate in the study.

Sample size was calculated at 245 according to the following equation:

$$
N=z^{2} \mathrm{pq} / \mathrm{d}^{2}
$$

Where $z=1.96, \mathrm{p}=0.2, \mathrm{q}=0.8$, and $\mathrm{d}=0.05$.
A stratified, simple, random sampling technique was used in selection of the study sample. The number of participants from any hospital was determined according to their proportion from the total number of the study. Participation in the study was voluntary, so when a randomly selected participant refused to participate, he/she was substituted by another participant from the list. There were 15 refusals to participate. Personnel working in the 3 selected hospitals who had a close contact with risk factors of HBV infection were included in this study. Personnel working in administrative positions were excluded.

The questionnaire used to collect data from study participants was designed by the authors. It comprised 3 parts: the first covered basic information such as age, sex, occupation, working hours per day, etc; the second part covered risk factors for HBV infections and the last part covered the result of $\mathrm{HBV}$ infection.

Informed consent was obtained from each participant after explaining the objective of the study, why these groups were selected to participate and that participation was voluntary. We also explained the methods used in diagnosis and informed the participants that any identifying information would not be disclosed in any report or publication.

SPSS was used to analyse the data. Tables were engendered describing the relationship between infection and risk factors, e.g. unsafe work area and unsafe procedures and practices.

\section{Laboratory work}

We collected $5 \mathrm{~mL}$ of venous blood in a Vacutainer tube from each of the participants. Serum was separated and kept at $-20^{\circ} \mathrm{C}$ until screening.

Enzyme-linked immunosorbent assay (ELISA) commercial kits (Biokit, Spain) were used to detect HBV. Serum samples were added and incubated for 1 hour. Plates were washed 
with approximately $350 \mu \mathrm{L}$ of washing buffer then conjugate (Biokit, Spain) was added and the plate incubated for 30 minutes. This allowed antigen in the sample to bind with the goat anti-HBs conjugated to peroxidase in order to form antigen-antibody complex. The plates were washed again to remove unbound materials, substrate added and colour developed in positive plates (control and positive samples). The reaction was stopped by adding sulphuric acid. The colour was read as optical density in order to determine the result of the test [13].

\section{Results}

A total of 245 health workers participated in this study, 168 (68.6\%) females and 77 (31.4\%) males. They included 23 surgeons, 37 laboratory staff, 6 dentists, 73 nurses and 106 domestic staff.

Twelve (4.89\%) of the participants tested positive for hepatitis B surface antigen (HBsAg): 6 nurses, 4 domestic staff and 2 laboratory staff (Table 1 ). All 6 nurses positive for HBsAg were from Omdurman hospital, which had $7(5.5 \%)$ positive cases, while 1 of the laboratory staff was from Khartoum hospital and the other from Khartoum north (Table 1)

Only 37 (15.1\%) of the participants said that they had attended a biosafety training course on how to deal with high risk materials.

Overall, 125 (51.0\%) participants indicated that they had a history of needle-stick or sharps injuries during their work; 79 of these declared that they had been exposed to needle-sticks more than 1 time while 46 said that they had been exposed only 1 time in their life. Regarding the application of biosafety precautions (disinfectant spills, wearing protective clothing etc.) during their work, 61 (24.9\%) indicated that they always followed the precautions, and 150 (61.2\%) indicated that they sometimes applied the precautions. The remaining 34 (13.9\%) said that they did not follow the biosafety precautions.

Only 52 (21.4\%) of the study sample, including 7 of the 23 surgeons, said that they always wore gloves during their work (Table 2). Decontamination of equipment and area of work before and after the work was always carried out by $56(22.9 \%)$ of the study participants while 35 (14.2\%) said they did not comply with the precautions at all (Table 2).

Only 11 participants had had the full dose of the hepatitis $B$ vaccination (Table 3). The vast majority, 93.1\%, had no history of vaccination.

\section{Discussion}

Previous findings have indicated that the positivity for HBsAg in Sudan is $16 \%-20 \%$ [12]. In this study, among 245 participants selected from 3 hospitals, 12 (4.9\%) tested positive.

Participation of healthcare workers varied according to occupation, but the participation of surgeons was low in Khartoum and Omdurman hospitals. The main reason in Khartoum hospital was that the authority refused to allow staff to participate in this study; they stated that they had already started testing doctors for $\mathrm{HBV}$ and did not want to repeat the issue. In Omdurman hospital, in contrast, the surgeons themselves refused to take part in the study but did not provide any justification or reasons for their refusal.

The study findings indicated that surgeons were more committed than other categories to a policy of vaccination. Infection with hepatitis $B$ virus was highest in nurses, and they had a very low vaccination uptake (97.2\% had not received any dose of hepatitis $B$ vaccine). Our findings also indicated that the surveyed hospitals did not have a policy for hepatitis B vaccination. In fact, vaccination for $\mathrm{HBV}$ was obtained by the individuals themselves independent of the hospitals. Coverage was very low overall: only $4.5 \%$ of the health-care workers who participated in the study received the full dose. In contrast, $15.8 \%$ of the healthcare workers in an Egyptian study reported receiving the full dose of hepatitis B vaccine [14].

Regarding biosafety precautions, most of the nurses said that they sometimes applied precautions. In a seroprevalence study of viral hepatitis

\begin{tabular}{|c|c|c|c|c|}
\hline \multirow[t]{2}{*}{ Variable } & \multicolumn{2}{|c|}{$\begin{array}{l}\text { Hepatitis B +ve } \\
\quad(n=12)\end{array}$} & \multicolumn{2}{|c|}{$\begin{array}{c}\text { Total } \\
(n=245)\end{array}$} \\
\hline & No. & $\%$ & No & $\%$ \\
\hline \multicolumn{5}{|l|}{ Occupation } \\
\hline Dentist & 0 & 0.0 & 6 & 2.5 \\
\hline Surgeon & 0 & 0.0 & 23 & 9.4 \\
\hline Laboratory staff & 2 & 5.4 & 37 & 15.1 \\
\hline Nurse & 6 & 8.2 & 73 & 29.8 \\
\hline Domestic staff & 4 & 3.8 & 106 & 43.3 \\
\hline \multicolumn{5}{|l|}{ Sex } \\
\hline Male & 5 & 6.5 & 77 & 31.4 \\
\hline Female & 7 & 4.2 & 168 & 68.6 \\
\hline \multicolumn{5}{|l|}{ Site (hospital) } \\
\hline Omdurman & 7 & 5.6 & 126 & 51.4 \\
\hline Khartoum North & 4 & 5.0 & 80 & 32.7 \\
\hline Khartoum & 1 & 2.6 & 39 & 15.9 \\
\hline
\end{tabular}




\begin{tabular}{|c|c|c|c|c|c|c|c|c|c|c|c|c|c|}
\hline \multirow[t]{3}{*}{ Variable } & \multicolumn{6}{|c|}{ Use decontamination precautions } & \multicolumn{6}{|c|}{ Wear gloves } & \multirow[t]{3}{*}{ Total } \\
\hline & \multicolumn{2}{|c|}{ Always } & \multicolumn{2}{|c|}{ Sometimes } & \multicolumn{2}{|c|}{ Never } & \multicolumn{2}{|c|}{ Always } & \multicolumn{2}{|c|}{ Sometimes } & \multicolumn{2}{|c|}{ Never } & \\
\hline & No. & $\%$ & No. & $\%$ & No. & $\%$ & No. & $\%$ & No. & $\%$ & No. & $\%$ & \\
\hline \multicolumn{14}{|l|}{ Occupation } \\
\hline Surgeon & 8 & 34.8 & 11 & 47.8 & 4 & 17.4 & 7 & 30.4 & 16 & 69.6 & 0 & 0.0 & 23 \\
\hline $\begin{array}{l}\text { Laboratory } \\
\text { staff }\end{array}$ & 13 & 35.1 & 18 & 48.7 & 6 & 16.2 & 18 & 48.7 & 17 & 45.9 & 2 & 5.4 & 37 \\
\hline Dentist & 3 & 50.0 & 1 & 16.7 & 2 & 33.3 & 5 & 83.3 & 1 & 16.7 & 0 & 0.0 & 6 \\
\hline Nurse & 17 & 23.3 & 55 & 75.3 & 1 & 1.4 & 13 & 17.8 & 57 & 78.1 & 3 & 4.1 & 73 \\
\hline $\begin{array}{l}\text { Domestic } \\
\text { staff }\end{array}$ & 15 & 14.2 & 69 & 65.1 & 22 & 20.7 & 9 & 8.5 & 59 & 55.7 & 38 & 35.8 & 106 \\
\hline Total & 56 & 22.9 & 154 & 62.9 & 35 & 14.2 & 52 & 21.5 & 150 & 61.0 & 43 & 17.5 & 245 \\
\hline \multicolumn{14}{|l|}{ Sex } \\
\hline Male & 24 & 9.8 & 44 & 18.0 & 9 & 3.7 & 19 & 24.7 & 47 & 61.0 & 11 & 14.3 & 77 \\
\hline Female & 33 & 13.5 & 111 & 45.3 & 24 & 9.8 & 30 & 17.9 & 106 & 63.1 & 32 & 19.0 & 168 \\
\hline Total & 57 & 23.5 & 155 & 63.3 & 33 & 13.5 & 49 & 20.0 & 153 & 62.3 & 43 & 17.6 & 245 \\
\hline
\end{tabular}

markers in the main hospital in Yemen, health-care workers were tested for HBsAg: the rate of infection was 9.9\% [15]. In another study among hospital health-care workers in Saudi Arabia, $13 \%$ of the study sample showed previous infection with hepatitis $B$ virus [16]. In a separate study conducted among high risk groups in Palestine, the rate of infection among health-care workers was 9.6\% [17]. In the above mentioned studies, the infection rate is high compared with our study. In a study conducted in a services hospital in Lahore, Pakistan, HBsAg positivity was $5 \%$ in health-care workers. This is similar to our findings [18]. However, in a study on Moroccan health-care workers, HBsAg was only 1\% [19] and seroprevalence of $\mathrm{HBsAg}$ among health-care workers in a Korean study was $2.4 \%[20]$.

In a study to assess occupational exposure to hepatitis infection among Turkish nurses, the positivity rate was $18.7 \%$; this is greater than the $8.2 \%$ reported for the nurses in our study [21].
In study conducted to assess knowledge, attitudes and practices of health-care workers regarding needle-stick injuries in Pakistan, $45 \%$ of the participants had had a needle-stick injury in the past. This is similar to our study with $51.0 \%$ of the participants indicating that they had had needle-stick injuries during work [22].

Avaccination policy for $\mathrm{HBV}$ should be implemented in health-care workers at high risk of contracting hepatitis $B$ virus infection. All precautions and

\begin{tabular}{|c|c|c|c|c|c|c|c|c|c|}
\hline \multirow[t]{3}{*}{ Variable } & \multicolumn{8}{|c|}{ History of vaccination } & \multirow{3}{*}{$\begin{array}{c}\text { Total } \\
\text { No. }\end{array}$} \\
\hline & \multicolumn{2}{|c|}{3 doses $^{a}$} & \multicolumn{2}{|c|}{2 doses } & \multicolumn{2}{|c|}{1 dose } & \multicolumn{2}{|c|}{ Never } & \\
\hline & No. & $\%$ & No. & $\%$ & No. & $\%$ & No. & $\%$ & \\
\hline \multicolumn{10}{|l|}{ Occupation } \\
\hline Surgeon & 7 & 30.5 & 1 & 4.3 & 2 & 8.7 & 13 & 56.5 & 23 \\
\hline Laboratory staff & 1 & 2.7 & 1 & 2.7 & 1 & 2.7 & 34 & 91.9 & 37 \\
\hline Dentist & 2 & 33.3 & 0 & 0.0 & 0 & 0.0 & 4 & 66.6 & 6 \\
\hline Nurse & 1 & 1.4 & 1 & 1.4 & 0 & 0.0 & 71 & 97.2 & 73 \\
\hline Domestic staff & 0 & 0.0 & 0 & 0.0 & 0 & 0.0 & 106 & 100.0 & 106 \\
\hline Total & 11 & 4.5 & 3 & 1.2 & 3 & 1.2 & 228 & 93.1 & 245 \\
\hline \multicolumn{10}{|l|}{ Sex } \\
\hline Male & 4 & 5.2 & 0 & 0.0 & 1 & 1.3 & 72 & 93.5 & 77 \\
\hline Female & 7 & 4.2 & 3 & 1.8 & 2 & 1.2 & 156 & 92.8 & 168 \\
\hline Total & 11 & 4.5 & 3 & 1.2 & 3 & 1.2 & 228 & 93.1 & 245 \\
\hline
\end{tabular}

${ }^{a}$ Full dose. 
protection from sharps and needle-stick injuries should be encouraged and enforced. The health authority in hospitals should adopt a post-exposure testing protocol of the staff at risk of exposure to hepatitis virus.

\section{Acknowledgements}

This study was funded by the World Health Organization Eastern Mediterranean Regional Office Research Policy and Cooperation Unit.
Our thanks are extended to the Research Directorate, Federal Ministry of Health, for their technical support. We are also grateful to Professor Suad Sulaiman for editing and finalizing the manuscript.

\section{References}

1. Seeger C, Mason WS. Hepatitis B virus biology. Microbiology and Molecular Biology Reviews, 2000, 64(1):51-68.

2. Mahony FJ. Update on diagnosis, management and prevention of hepatitis B virus infection. Clinical Microbiology Reviews, 1999, 12:351-366.

3. Bond WW et al. Survival of Hepatitis B virus after dry storage for one week. Lancet, 1981, 1:550-551.

4. Mast EE, Alter MJ. Prevalence of hepatitis B virus among health care personnel. In Ellis RW, ed. Hepatitis B vaccine in clinical practice. New York, Marcel Dekker, 1993:295-307.

5. Kunches LM et al. Hepatitis B exposure in emergency medical personnel: prevalence of serologic markers and need for immunization. American Journal of Medicine 1983, 75:269-272.

6. McCarthey MC et al. Hepatitis B and C serosurvey. Transactions of the Royal Society of Tropical medicine \& Hygiene, 1994, 88(5):534-536.

7. McCarthey MC et al. HIV-1 and hepatitis B transmission in Sudan. AIDS, 1989, 3:725-729.

8. McCarthey MC et al. Hepatitis B and HIV in Sudan. A serosurvey for Hepatitis B and HIV antibodies among sexually active heterosexuals. American Journal of Tropical Medicine and Hygiene, 1989, 41(6):721-731.

9. Hyams KC et al. Epidemiology of hepatitis B virus in Gezira region Sudan. American Journal of Tropical Medicine and Hygiene, 1989, 40(2):200-206.

10. El Arabi MA et al. Non A-non B hepatitis in Omdurman, Sudan. Journal of Medical Virology, 1987, 21:217-222.

11. El Sanousi OM. The risk of HIV and hepatitis B infection to the medical staff during surgery [Thesis No. o/237]. Khartoum, University of Khartoum, 1997.

12. Qirbi N, Hal AJ. Epidemiology of hepatitis B virus infection in the Middle East. Eastern Mediterranean Health Journal, 2001, 7(6):1034-1045.
13. Lequin RM. Enzyme immunoassay (EIA)/enzyme-linked immunosorbent assay (ELISA). Clinical Chemistry, 2005, 51(12):24152418.

14. Talaat $\mathrm{M}$ et al. Occupational exposure to needlestick injuries and hepatitis B vaccination coverage among health care workers in Egypt. American Journal of Infection Control, 2003, 31(8):469-474.

15. Al Huraibi MA et al. Seroprevalence of markers of viral hepatitis in Yemen health care workers. Journal of Medical Virology, 2004, 73(4):562-565.

16. Daw MA et al. Seroepidemiology of hepatitis B virus markers among hospital health care workers. Analysis of certain potential risk factors. Saudi Medical Journal, 2000, 21(12):1157-1160.

17. Jadallah RI et al. Prevalence of hepatitis B virus markers among high risk groups in Palestine. Medical Journal of Islamic World Academy of Sciences, 2005, 15(4):157-160.

18. Rehman $\mathrm{K}$ et al. Prevalence of seromarkers of HBV and HCV in health care personnel and apparently healthy blood donors. Journal of the Pakistan Medical Association, 1996, 46(7):152-154

19. Djeriri $\mathrm{K}$ et al. Hepatitis B in Moroccan health care workers. Occupational Medicine, 2008, 58(6):419-424.

20. Shin B et al. Seroprevalence of hepatitis B virus among health care workers in Korea.Journal of Korean Medical Science, 2006 , 21:58-62.

21. Kosgeroglu N et al. Occupational exposure to hepatitis infection among Turkish nurses. Epidemiology and Infection, 2004 132(1):27-33.

22. Zafar A et al. Knowledge, attitudes and practices of health care workers regarding needle-stick injuries at a tertiary care hospital in Pakistan. Journal of the Pakistan Medical Association, 2008, 58(2):57-60. 